\title{
A STUDY ON THE IMPACT OF CREDIT RISK ON THE PROFITABILITY OF STATE BANK OF INDIA (SBI)
}

\author{
Jeslin Sheeba. J \\ Department of Management Studies, University College of Engineering, BIT Campus, Anna University, India
}

\begin{abstract}
The study is aimed at investigating the impact of Credit risk on the profitability of the bank. Through extensive literature review, various factors that influence Credit risk are identified as Capital adequacy ratio (CAR), Nonperforming Asset ratio (NPA), Loan to Deposit Ratio (LDR), Cost per Loan Ratio (CLR), Provision Coverage Ratio (PCR), Leverage Ratio (LR), and Nonperforming Asset to Asset Ratio (NPAAR). Return on Equity (ROE) is identified as the indicator of profitability. The secondary data is collected from the Annual reports of the State Bank of India for twenty years (1997-2016). The data is analysed using multiple regression. The result showed that NPAAR alone have significant negative impact on ROE and other indicators of credit risk do not have significant impact on ROE. But overall credit risk has significant impact on profitability of State Bank of India. State bank of India faces credit risk due to inefficient Credit risk management. So it is advised to improve Credit risk management practices in State Bank of India. State Bank of India can minimise the Credit risk by reducing the Nonperforming assets by framing strict loan policies.
\end{abstract}

\section{Keywords:}

Credit Risk, Profitability, State Bank of India, Multiple Regressions

\section{INTRODUCTION}

Credit risk is the probability that a bank borrower may default on a debt by failing to make required payment in as per the agreed terms and the lender may lose the principal of the loan or the interest. Profitability indicates the capacity of the bank to carry risk and/or increase their capital. It represents the effectiveness of the bank and quantifies the quality of management. As per RBI, Gross NPA has increased to 7.6 in March 2016 which was 5.1 in September 2015 and 4.6 in March 2015.

\section{RISE \& RISE OF STRESSED LOANS}

The RBI's projections show the gross NPA of banking sector could go up to $8.5 \%$ by March 2017

\begin{tabular}{|c|c|c|c|c|}
\hline (in \%) & $\begin{array}{l}\text { Net } \\
\text { NPA }\end{array}$ & $\begin{array}{l}\text { Gross } \\
\text { NPA }\end{array}$ & $\begin{array}{l}\text { Stressed } \\
\text { assets* }\end{array}$ & ( \\
\hline March 2013 & - & 3.4 & 9.2 & ng \\
\hline September 2013 & 2.3 & 4.2 & 10.2 & mirrors in the \\
\hline March 2014 & 2.2 & 4.1 & 10 & corporate sec- \\
\hline September 2014 & 2.5 & 4.5 & 10.7 & with in \\
\hline March 2015 & 2.5 & 4.6 & 11.1 & $\begin{array}{l}\text { order to revive } \\
\text { credit growth }\end{array}$ \\
\hline September 2015 & 2.8 & 5.1 & 11.3 & - RAGHURAM \\
\hline March 2016 & 4.6 & 7.6 & 11.5 & $\begin{array}{l}\text { RAJAN, } \\
\text { RBI Governor }\end{array}$ \\
\hline
\end{tabular}

Fig.1. Nonperforming Asset of Banking Sector (Source: The Hindu-Business Economy-Bank-NPAs)
The RBI projection shows that the Gross NPA could go up to $8.5 \%$ by March 2017. The rise in NPA is due to increased Credit risk which affects the profit of banking sector. Among the various risk (Credit risk, Operational risk, reputation risk, market risk, legal risk) faced by the bank, Credit risk is the most significant risk faced by the bank considering that granting credit as one of the major source of income for the bank. State Bank of India is the top public sector bank in India. The research is done to find whether the credit risk faced by the State Bank of India affects the profitability of the bank over twenty years.

\section{RESEARCH OBJECTIVES}

- To find the impact of Credit Risk on the profitability of State Bank of India.

- To find, is there any statistically significant relationship between CAR and profitability of State Bank of India measured by ROE.

- To find, is there any statistically significant relationship between NPA and profitability of State Bank of India measured by ROE.

- To find, is there any statistically significant relationship between LDR and profitability of State Bank of India measured by ROE.

- To find, is there any statistically significant relationship between CLR and profitability of State Bank of India measured by ROE.

- To find, is there any statistically significant relationship between PCR and profitability of State Bank of India measured by ROE.

- To find, is there any statistically significant relationship between LR and profitability of State Bank of India measured by ROE.

- To find, is there any statistically significant relationship between NPAAR and profitability of State Bank of India measured by ROE.

\section{LITERATURE REVIEW}

\subsection{CREDIT RISK}

$\mathrm{Li}$ and Zou [6] said among the various risks faced by the bank Credit risk is the most significant risk that could adversely affect the bank, considering that granting credit is one of the main sources of income in commercial banks. And defined Credit risk management as a planned tactics of management of uncertainty by evaluation of the risk, formulation of strategies to handle the risk and lessening of risk by means of managerial 
assets and declared that the management of the risk related to that credit affects the profitability of the banks.

Psillaki et al. [12] defined Credit risk as one of important risk faced by the banks due to the nature of its activities. Effective management of credit risk exposure of the banks encourages the viability and profitability of their business and also contribute to systemic stability and efficient distribution of capital in the economy.

Gestel and Baesens [16] defined Credit risk as the nonpayment of a small number of customers might result in a large loss for the bank.

Credit risk is the risk of loss due to the default of an obligation by the obligator in terms of a loan or other forms of credit.

Chen and Pan [18] defined credit risk as the degree of value variations in debt instruments and derivatives due to variations in the original credit quality of borrowers and counterparties.

Coyle [14] defined credit risk as the loss due to the refusal or inability of credit customers to pay what is outstanding in full and on time. It is a probability of loss to a bank due to default by the bank borrowers (counterparties) who fails repay the borrowed money on time, or the borrowed amount becomes irrecoverable. It is due to the failure of borrower to fulfil their financial commitment with bank as per the agreed terms and conditions.

Gestel and Baesens [16] defined credit risk as the risk that a borrower defaults and does not honour its obligation to service debt. It can occur when the counterpart is unable to pay or cannot pay on time.

Saita [7] Credit is defined as the risk resulting from an unexpected drop in the credit quality of counterparty (e.g. a bond issuer or bank borrower).

\subsection{PROFITABILITY}

Li and Zou [6] defined profitability as a gauge of capability of the bank to bear risk and/or raise the capital of bank and it implies effectiveness of the bank and gauges the excellence of management.

Spaulding [5] said that similar to all businesses, banks earn more money than what they pay in expense to make profit. The bank profit by charging fees for its services and the interest earned from its assets. The key expense of the bank is due the interest paid for its liabilities. The foremost assets of a bank are the loans provided to individuals, businesses, and other organizations and the securities that it owns, while the liabilities are the deposits, money borrowed from other banks and commercial paper sold in the money market. The author said, banks also increase its profits by using leverage and profits of the banks can be measured as a return on assets and as a return on equity. And because of the leverage, banks earn larger return on equity than on assets.

Credit Rating and Information Services of India [13] revealed that the profitability of private sector banks was primarily due to the increase in intensity of treasury income and not due to reduction in operating expenses. But for public sector and foreign banks, the profitability is due to the reduction in operating expenses which accounts for over 80 per cent of the total assets of all scheduled commercial banks

\subsection{DuPont ANALYSIS}

Alimazari [17] said that DuPont model was created in 1920 and is being used even now for assessment of the profitability. DuPont model is the product of two ratios, net profit margin and total assets turnover which equals return on assets (ROA). DuPont model was widely used for financial analysis since ROA is affected by profitability measure and efficiency measure. Later, the concentration in financial analysis moved from return on asset (ROA) to return on equity (ROE).

$\mathrm{Li}$ and Zou [6] They said since it was difficult to find the appropriate indicators to get accuracy of their test, DuPont system which measures the financial performance based on analysis of Return on Equity model (ROE) and Return on Asset (ROA) is used.

Guru et al. [9] indicated the advantages of using ratios to measure the profitability of bank. The author said that the ratios were used to measure the profitability because ratios are inflation invariant and will not be influenced by variations in price level.

Besides, banks are multi-products firms they uses ratio measures to eliminate problems associated with crosssubsidization between products and services [15].

\subsection{VARIABLES, TOOLS AND RESULT}

$\mathrm{Li}$ and Zou [6] used Capital Adequacy ratio (CAR) and Nonperforming Asset to Asset ratio (NPAAR) as the measures of credit risk management. They used Return on Asset and Return on Equity as the measure of profitability as per DuPont system. They investigated to find if there is an association between credit risk management and profitability by taking 47 largest commercials banks in Europe as sample and calculated the ratios for the period of 2007 to 2012 and also investigated whether the relationship is sTable.or fluctuating. They used descriptive statistics, multiple regression analysis technique to find whether the association exists and they calculated mean and standard deviation to find whether the relationship is sTable.or fluctuating. The study revealed that the NPAAR alone had significant impact on ROE and ROA and credit risk management have positive effect on profitability of commercial banks. And also they found that the relationships between all the proxies are not sTable.but fluctuating.

Gizaw et al. [3] examined the influence of credit risk on profitability of 8 commercial banks in Ethiopia for the period of 2003 to 2014. The data was analysed using descriptive statistics and panel data regression. The study revealed that the Credit risk measured by nonperforming loan, loan loss provisions and capital adequacy have significant impact on the profitability measured by ROA of 8 commercial banks in Ethiopia.

Poudel [8] tried to discover various factors relevant to credit risk management and its influence on the financial performance of the 31 banks in Nepal for the period of 2001-2011. Used default rate, cost per loan assets and capital adequacy ratio as the measure of Credit risk management and ROA as a measure of profitability. They used descriptive statistics, correlation and regression to analyse the data. Findings revealed that measures of credit risk management have significant inverse effect on financial performance of the bank. 
Bayyoud and Sayyad [2] studied the association between credit risk management and profitability of Palestine investment and commercial banks. They used Nonperforming Loan Ratio as a measure of credit risk management and ROE as the measure of profitability. Regression was used to analyse the data. From the findings it is inferred that there is no effect of credit risk on profitability of Palestine commercial and investment banks. From the findings it is inferred that the relationship between the Palestinian commercial and investment banks is null.

Kaaya and Pastory [4] conducted the study to find the association between the credit risk measured by NPLR and bank performance measured by ROA of 11 banks in Tanzania. They used regression to analyse the data. The findings of the study revealed that the indicator of credit risk has negative correlation which means, if the credit risk is higher, then the bank performance will be lower.

Abiola and Olausi [1] investigated the effect of credit risk management on the performance of commercial banks for the period of 2005 - 2011 in Nigeria. The panel regression model was used for the analysis of data. The findings revealed that credit risk management measured by Non-Performing Loans (NPL) and Capital Adequacy Ratio (CAR) has a significant impact on the profitability measured by Return on Equity (ROE) and Return on Asset (ROA) of commercial banks' in Nigeria.

Samuel [10] studied the effect of credit risk on the performance of top five Nigerian commercial banks. The need for that study was driven by the negative consequences of the credit risk that affects profitability of the bank and their outcomes functioned as the base to deliver policy measures to the stakeholders on how to deal with the credit risk permissible to improve the value of assets of the bank and diminish bank risk. They used Non-performing loan and loan and Advances ratios as the measure of credit risk and ROA as a measure of profitability. The result showed that the ratio of Non-performing loan to loan and Advances and loan and advances to total deposit negatively impact the profitability. This study showed that there is a major association between bank performance and credit risk management.

Alshatti [11] examined the influence of management of credit risk on financial performance of 13 commercial banks in Jordanian for the period of 2005 to 2013. Non-performing loans to Gross loans, Provision for facilities loss to Net facilities and the leverage ratio were used as a measure of management of credit risk. ROA and ROE were used as a measure of financial performance. Two mathematical models were developed and regression was used to find the relationship. Findings concluded that the indicators of credit risk management have an influence on financial performance of commercial banks in Jordanian.

\section{RESEARCH METHODOLOGY}

\subsection{RESEARCH DESIGN}

The main task is to find the causes and to say to what extent they lead to such effects i.e. it is to explain the causal relationship between variables. So explanatory research design is used to find the cause and effect relationship between the various indicators of credit risk and the indicator of profitability.

\subsection{SECONDARY DATA}

The secondary data is collected from the Annual report of State of bank of India for 20 years (1997-2016), published in the website of State bank of India.

\subsection{TOOL USED FOR ANALYSIS}

Multiple Regression is employed to find the impact of credit risk indicators on profitability indicator of State Bank of India. MS Excel is used to perform Multiple Regression.

\section{MODEL SPECIFICATION}

$$
\begin{aligned}
\mathrm{ROE} & =\beta_{0}+\beta_{1} \mathrm{CAR}+\beta_{2} \mathrm{NPA}+\beta_{3} \mathrm{LDR}+\beta_{4} \mathrm{CLR} \\
& +\beta_{5} P C R+\beta_{6} L R+\beta_{7} N P A A R+e
\end{aligned}
$$

where,

$\beta_{0}$ - Constant term

$\beta_{1}-\beta 7$ are the coefficients of independent variables

$e$ - Error term

Model in Eq.(1) measures the impact of credit risk indicators on profitability of State Bank of India measured by (ROE). Indicator of profitability, ROE is the dependent variables. Indicators of Credit risk, CAR, NPA, LDR, CLR, PCR, LR, and NPAAR are the independent variable

\section{DEFINITION OF VARIABLES}

\begin{tabular}{|c|c|}
\hline Description & Formula \\
\hline Return On Equity (ROE) & $\begin{array}{c}\text { (Net income) } / \text { (Total equity } \\
\text { capital) } \times 100\end{array}$ \\
\hline $\begin{array}{c}\text { Capital Adequacy Ratio } \\
\text { (CAR) }\end{array}$ & $\begin{array}{c}(\text { (Tier } 1 \text { capital }+ \text { Tier } 2 \text { capital }) \\
/ \text { Risk weighted asset }) \times 100\end{array}$ \\
\hline $\begin{array}{l}\text { Nonperforming Asset } \\
\text { Ratio (NPA) }\end{array}$ & $\begin{array}{l}\text { (Net Nonperforming asset / } \\
\text { Total advances }) \times 100\end{array}$ \\
\hline $\begin{array}{l}\text { Loan to Deposit Ratio } \\
\text { (LDR) }\end{array}$ & $\begin{array}{c}\text { (Total loans / Total Deposits) } \\
\times 100\end{array}$ \\
\hline Cost Per Loan Ratio (CLR) & $\begin{array}{l}\text { (Total operating cost / Total } \\
\text { amount of loans disbursed) } \times \\
100\end{array}$ \\
\hline $\begin{array}{l}\text { Provision Coverage Ratio } \\
\text { (PCR) }\end{array}$ & $\begin{array}{c}\text { (Total provision / Gross NPA) } \\
\times 100\end{array}$ \\
\hline Leverage Ratio (LR) & (Total debt / Total equity) $\times 100$ \\
\hline $\begin{array}{l}\text { Nonperforming Asset to } \\
\text { Asset Ratio (NPAAR) }\end{array}$ & $\begin{array}{c}\text { (Net Nonperforming asset / } \\
\text { Total asset) } \times 100\end{array}$ \\
\hline
\end{tabular}

Table.1. Description of Variables

\subsection{PROXY OF PROFITABILITY}

Return on Equity ROE is identified as a good indicator of profitability of the bank. Return on Equity indicates the profit made out of Shareholder's fund. 


\subsection{PROXIES OF CREDIT RISK}

Capital Adequacy Ratio CAR indicates the bank's ability to absorb the loss. It acts like an air bag in the car.

Nonperforming Asset Ratio NPA indicates the loans that are default for the period of more than 90 days and the assets that are acquired as result of foreclosure.

Loan to Deposit Ratio indicates the liquidity of the bank i.e., it indicates the bank's ability to withstand the cash withdrawal made by the customer as the loans were made out of the deposits made by the customers.

Cost per Loan Ratio CLR indicates the cost incurred by the bank in providing one unit of loan.

Provision Coverage Ratio PCR Provision coverage indicates the provision made to cover the loss that might occur from the non-performing assets.

Leverage Ratio LR: Leverage means borrowing money and investing with the aim of earning more profit than the money spent on borrowing. The bank provides loan to the customer out of deposits made with the aim of earning more profit. Excessive leverage increases the credit risk faced by the bank.

Nonperforming Asset to Asset Ratio NPAAR indicates the asset quality of the bank i.e., it indicates the bank's nonperforming assets out of the total asset.

\section{FINDINGS}

Table.2. Model Summary

\begin{tabular}{|c|c|c|c|c|}
\hline Model & $\begin{array}{c}\text { Multiple } \\
\text { R }\end{array}$ & $\begin{array}{c}\text { R } \\
\text { Square }\end{array}$ & $\begin{array}{c}\text { Adjusted R } \\
\text { Square }\end{array}$ & $\begin{array}{c}\text { Std. Error of } \\
\text { the Estimate }\end{array}$ \\
\hline 1 & $.813^{\mathrm{a}}$ & .661 & .463 & 1.81165 \\
\hline
\end{tabular}

In Table.2, Multiple $\mathrm{R}$ denotes the correlation coefficient between the dependent variable and independent variables. Multiple R value of 0.8129 (81.29\%), shows strong positive correlation between the dependent variable and independent variables.

Table.3. ANOVA

\begin{tabular}{|c|c|c|c|c|c|}
\hline \multicolumn{7}{|c|}{ ANOVA $^{\text {a }}$} \\
\hline Model & $\begin{array}{c}\text { Sum of } \\
\text { Squares }\end{array}$ & Df & $\begin{array}{c}\text { Mean } \\
\text { Square }\end{array}$ & F & Sig. \\
\hline Regression & 76.701 & 7 & 10.957 & 3.339 & $.032^{\mathrm{b}}$ \\
\hline Residual & 39.385 & 12 & 3.282 & & \\
\hline Total & 116.086 & 19 & & & \\
\hline
\end{tabular}

$\mathrm{R}$ Square is called coefficient of determination, gives the contribution made by regression in explaining the variations in the dependent variable. $\mathrm{R}$ square value is 0.6607 , which means $66.07 \%$ of variation in the dependent variable is explained by the independent variables. About $33.93 \%$ are accounted by error or residual terms. So the model fitted is fairly accurate.

The Table. 3 presents the ANOVA, which is used to find the significance of the model. ANOVA presents the significance value of 0.032 which is less than 0.05 . Since the test for significance is done at $95 \%$ confidence level, the significance value has to be less or equal to 0.05 for the model to be significant. From Table.3, it is inferred that there is a significant relationship between the dependent variable and independent variables. This finding therefore indicates that all the Credit risk indicators have direct relationship with performance and the model is significant.

Table.4. Coefficients

\begin{tabular}{|c|c|c|}
\hline \multirow{2}{*}{ Model } & Unstandardized Coefficients & \multirow{2}{*}{ Sig. } \\
\cline { 2 - 3 } & Beta & \\
\hline (Constant) & 18.74 & .304 \\
\hline CAR & .705 & .244 \\
\hline NPA & .044 & .926 \\
\hline LDR & -.028 & .714 \\
\hline CLR & -.147 & .936 \\
\hline PCR & -.155 & .324 \\
\hline LR & -.142 & .756 \\
\hline NPAAR & -3.590 & .004 \\
\hline
\end{tabular}

Since the test for significance is done at $95 \%$ confidence level, the significance value has to be less than 0.05 for the significant impact of credit risk indicators on Profitability indicator.

The Table.4, Observation of significance level indicates that NPAAR of $0.004<0.05$ has significance impact on ROE. And the Beta value is -3.590 which implies that NPAAR has a negative impact on ROE, which means that a unit rise in NPAAR will lower ROE by 3.590. The significant negative impact of NPAAR on ROE is in accordance with the previous research which is conducted by $\mathrm{Li}$ and Zou [6] in Europe to study the impact of credit risk management on profitability of the commercial banks.

CAR has a significance level of $0.304>0.05$. So CAR doesn't have significant impact on ROE. This result is in accordance with $\mathrm{Li}$ and Zou [6]. This result is not accordance with some of the previous researches conducted by Poudel [8], Abiola and Olausi [1], Gizaw and Sujata [3] in which they had significant impact of CAR on ROE.

NPA has a significance level of $0.926>0.05$. So NPA doesn't have significant impact on ROE. This result is in accordance with (Li and Zou, 2014). This result is not accordance with some of the previous researches conducted by Samuel [10], Poudel [8], Abiola and Olausi [1], Gizaw and Sujata [3] in which they had significant impact of NPA on ROE.

LDR has a significance level of $0.714>0.05$. So LDR doesn't have significant impact on ROE. This result is not in accordance with Samuel [10], as in the study LDR had significant impact on ROE.

CLR has a significance level of $0.936>0.05$. So CLR doesn't have significant impact on ROE. This result is not in accordance with Poudel [8] as in the study, CLR had significant impact on ROE.

PCR has a significance level of $0.324>0.05$. So PCR doesn't have significance impact on ROE. This result is not in accordance with Alshatti [11], Gizaw and Sujata [3] in which the study had significant impact of PCR on ROE. 
LR has a significance level of $0.756>0.05$. So LR doesn't have significant impact on ROE. This result is not in accordance with Alshatti [11] in which the study had significant impact of LR on ROE.

\section{CONCLUSION}

The general objectives of the study was to establish the impact of credit risk on profitability of State Bank of India and specific objectives were to establish impact of Capital adequacy ratio (CAR), Nonperforming Asset ratio (NPA), Loan to Deposit Ratio (LDR), Cost per Loan Ratio (CLR), Provision Coverage Ratio (PCR), Leverage Ratio (LR) and Nonperforming Asset to Asset Ratio (NPAAR) on Return On Equity. The result showed that NPAAR alone have significant, negative impact on ROE and other variables do not have significant impact on ROE. It can be concluded that overall credit risk have significant impact on the profitability of State Bank of India. State bank of India faces credit risk due to ineffective Credit risk management. So it is advised to improve Credit risk management practices in State Bank of India. State Bank of India can minimise the Credit risk by reducing the Nonperforming assets by framing strict loan policies.

\section{SUGGESTION FOR FUTURE RESEARCH}

Through extensive literature review, some ratios were identified as the indicators of credit risk and ROE as the indicator of profitability. Except those indicators involved in this study, there are other indicators of credit risk and profitability. It is recommended to include more indicators of credit risk and profitability to test the relationship in future. This study focuses on credit risk of State Bank of India. Except the credit risk there are other risks faced by the bank. In future research, we recommend including other risks faced by other bank, since the article focuses only on State Bank of India. It is recommended to include all the Public and Private sector banks in the future research.

\section{REFERENCES}

[1] Idowu Abiola and Awoyemi Samuel Olausi, "The Impact of Credit Risk Management on the Commercial Banks Performance in Nigeria", International Journal of Management and Sustainability, Vol. 3, No. 5, pp. 295-306, 2014.

[2] M. Bayyoud and N. Sayyad, "The Relationship between Credit Risk Management and Profitability between Investment and Commercial Banks in Palestine", International Journal of Economics and Finance, Vol. 7, No. 11, pp. 163-170, 2015.

[3] Million Gizaw, Matewos Kebede and Sujata Selvaraj, "The Impact of Credit Risk on Profitability Performance of
Commercial Banks in Ethiopia", African Journal of Business Management, Vol. 9, No. 2, pp. 59-66, 2015.

[4] Indiael Kaaya and Dickson Pastory, "Credit Risk and Commercial Banks Performance in Tanzania: A Panel Data Analysis", Research Journal of Finance and Accounting, Vol. 4, No. 16, pp. 55-62, 2013.

[5] Bank Profitability, Available at: http://thismatter.com/money/banking/bank-profits.htm.

[6] G.N. Navoda, "The Impact of Credit Risk Management on Profitability of Commercial Banks", Proceedings of the Undergraduates Research Conference, pp. 1-5, 2015.

[7] Francesco Saita, "Value at Risk and Bank Capital Management", Academic Press, 2010.

[8] Ravi Prakash Sharma Poudel, "The Impact of Credit Risk Management on Financial Performance of Commercial Banks in Nepal, International Journal of Arts and Commerce, Vol. 1, No. 5, pp. 9-15, 2012.

[9] Balachandher K. Guru, J. Staunton and B. Shanmugam, "Determinants of Commercial Bank Profitability in Malaysia", Proceedings of $12^{\text {th }}$ Annual Australian Finance and Banking Conference, pp. 1-22, 2002.

[10] Olawale Luqman Samuel, "The Effect of Credit Risk on the Performance of Commercial Banks in Nigeria", African Journal of Accounting, Auditing and Finance, Vol. 4, No. 1, pp. 29-52, 2013.

[11] Ali Sulieman Alshatti, "The Effect of Credit Risk Management on Financial Performance of the Jordanian Commercial Banks", Investment Management and Financial Innovations, Vol. 12, No. 1-2, pp. 338-345, 2015.

[12] Maria Psillaki, "Evaluation of Credit Risk based on Firm Performance", Econpapers, Vol. 201, No. 3, pp. 873-881, 2010.

[13] Profitability in Banks: A Study, Available at: http://www.banknetindia.com/banking/cstudy.htm

[14] Afifa Ferhi and Ridha Chkoundali, "Credit Risk and Efficiency: Comparative Study between Islamic and Conventional Banks during the Current Crises", Journal of Behavioural Economics, Finance, Entrepreneurship, Accounting and Transport, Vol. 3, No. 1, pp. 47-56, 2015.

[15] E.W. Chirwa, "Determinants of Commercial Banks Profitability in Malawi: A Cointegration Approach", Applied Financial Economics, Vol. 13, No. 8, pp. 565-571, 2010.

[16] Tony Van Gestel and Bart Baesens, "Credit Risk Management: Basic Concepts: Financial Risk Components, Rating Analysis, Models, Economic and Regulatory Capital", Oxford University Press, 2008.

[17] Ahmed Arif Almazari, "Financial Performance Analysis of the Jordanian Arab Bank by using the DuPont System of Financial Analysis", International Journal of Economics and Finance, Vol. 4, No. 4, pp. 86-94, 2012.

[18] K. Chen and C. Pan, ".An Empirical Study of Credit Risk Efficiency of Banking Industry in Taiwan", Web Journal of Chinese Management Review, Vol. 15, No. 1, pp. 1-16, 2012. 